\title{
Phylogenetic analysis of nitrogen-fixing and quorum sensing bacteria
}

\author{
Anushree Chaphalkar* and Nivedita Salunkhe \\ * Bioinformatics Lab, Department of Biotechnology, Vidya Pratishthan's Arts, Science and Commerce \\ College, M.I.D.C., Vidyanagari, Baramati 413 133, Pune, Maharashtra, India
}

\begin{abstract}
The present study involves phylogenetic analysis of distinguished bacterial population essentially grouped into functional attributes, namely nitrogen fixation and quorum sensing. The basis of this analysis are protein sequences of $\mathrm{NifH}$ (nitrogenase reductase), LuxA (Luciferase alpha subunit) and LuxS (Sribosyl homocysteine lyase) from $30,17,25$ species of bacteria respectively. These bacteria show vast diversity in terms of habitat mode of survival pathogenicity. Phylogenetic analysis gives an insight into the evolution and interrelationships of these microbial species. GeneBee, ClustalW and Phylip softwares were found to be satisfactory for the chosen work. Phylogenetic trees were constructed in the form of Cladograms, Phylograms and Unrooted radial trees. According to the results obtained, the most highly evolved group of organisms with respect to their nitrogenase reductase protein is that of Desulfovibrio vulgaris and Chlorobium phaeobacteriodes. Bacillus thuringiensis and Bacillus subtilis hold the most highly evolved forms of LuxS protein. Also knowledge abtained from the motif pattern analysis between Bradyrhizobium japonicum and Rhizobium leguminosarum NifH protein sequence are conserved and further analysis may show that there may be quorum sensing mediated gene regulation in host bacterium interaction. Phylogenetic analyses, thus, on the basis of highly conserved protein domains, universal in their existence, can provide a preamble to the actual 16S-rRNA based phylogeny or genomic analyses of phylogeny carried out in the wet lab.
\end{abstract}

Keywords: Phylogeny; Nitrogenase reductase; NifH; Quorum sensing; LuxA, LuxS.

\section{INTRODUCTION \\ Nitrogen Fixation}

Nitrogen makes up about $14 \%$ of the total dry weight of a bacterial cell, majorly concentrated in the proteins and nucleic acids of the cell. Some important groups of bacteria possess the ability to utilize gaseous nitrogen from the atmosphere. The atmosphere constitutes about $78.9 \%$ of nitrogen gas, which is significantly higher than other gases. Therefore, the nitrogen cycle is one of the most important biogeochemical cycles, maintaining the atmospheric balance of the universe [18]. The process of converting nitrogen in its gaseous form into ammonia is termed as nitrogen fixation, and is catalyzed by an enzyme called Nitrogenase (E.C 1.18.6.1). The unique property of this enzyme is its occurrence in aerobes, despite its inability to tolerate oxygen. Biological nitrogen fixation can be represented by the following equation, in which two moles of ammonia are produced from one mole of nitrogen gas, at the expense of 16 moles of ATP and a supply of electrons and protons:

$\mathrm{N} 2+8 \mathrm{H}++8 \mathrm{e}-+16 \mathrm{ATP}=2 \mathrm{NH} 3+\mathrm{H} 2+16 \mathrm{ADP}+16 \mathrm{Pi}$ $A$ variety of prokaryotes perform this reaction with the help of the nitrogenase enzyme complex. Nitrogenase is a two-component metallonzyme that catalyzes the Mg ATP-dependent reduction of $\mathrm{N} 2$ to yield two molecules of NH3. This enzyme consists of two proteins - an iron protein (Nitrogenase reductase) and a molybdenum-iron protein (Nitrogenase). The conventional nitrogenase is composed of a $\alpha 2 \beta 2$ tetramer; $\alpha$ and $\beta$ subunits are encoded by the nifD and nifK genes, respectively. While the nitrogenase reductase enzyme is encoded by the nifH gene $[1,2]$. It is observed that nitrogenase is found in diverse structural patterns, perhaps due to the interaction between the environment and the lifeforms with respect to nitrogen exchange $[5,10$, 12]. This in-silico study aims at understanding the phylogeny of nifH protein (Nitrogenase reductase), out of the whole enzyme complex. The basis of work is to focus on the most conserved domain, nifH, in diverse forms of prokaryotes. $[8,15]$ It is observed in certain cyanobacteria, that exposure to oxygen causes significant structural alterations in the nifH domain of the enzyme, indicating its pivotal role in insulating the other oxygen-sensitive domains of the enzyme $[6,7,19]$. Nitrogenase reductase is a functionally constant protein catalyzing N2 reduction, which is found in many phylogenetic lineages of Archaea, Proteobacteria, Cyanobacteria, Actinobacteria and Diazotrophs. Phylogenetic analysis of $\mathrm{NifH}$ protein may provide insights into the evolution of the bacteria. The selected genera of prokaryotes include nitrogen fixers either free-living or symbiotic. The habitat varies with respect to oxygen demand; they may be obligate aerobes, obligate anaerobes or facultative organism's .Use of Bioinformatics in understanding the similarities and differences between the chosen genera and establishing a possible evolutionary link between them, with respect to Nitrogenase reductase, is the scope of this study. Genomic analysis of nitrogen fixers has been extensively carried out $[3,4,16]$. Focus of most of the investigators has been to construct Phylogenetic tree(s) on the basis of 16S-rRNA and nif gene operon system. Microorganisms never functions as single cells. Bacterial populations coordinate their gene expression by producing and responding to a 
variety of intra- and intercellular signals termed "autoinducers" or Al molecules.

\section{Quorum Sensing}

This process of coordinating gene expression via the production, release, and sensing of $\mathrm{Al}$ molecules by bacteria is known as Quorum Sensing. When a critical threshold concentration of the signal molecule is achieved, bacteria detect its presence and initiate a signaling cascade resulting in changes of target gene expression [21, 22, 25]. Quorum sensing allows populations of bacteria to collectively control gene expression, and thus synchronize group behavior on the basis of local cell density.

The phenomenon of quorum sensing is widespread. It is used by Gram-negative and Gram-positive bacteria, both, to regulate a variety of physiological functions [24, 29] that include symbiosis, virulence, competence, conjugation, antibiotic production, motility, sporulation and biofilm formation. The first such system was described in Vibrio fischeri a symbiotic species that provides its marine eukaryotic hosts with light. Light emission, or bioluminescence, depends on transcription of the lux operon that consists of structural genes luxCDABEG, regulated by luxR, luxl and luxS genes. In general, Gram-negative bacteria use acylated homoserine lactones-AHLs- as autoinducers, and Gram-positive bacteria use processed oligopeptides to communicate. Many species of Gram-negative and Gram-positive bacteria produce Al-2 and, in every case, production of $\mathrm{Al}-2$ is dependent on the function encoded by the luxS gene [28]. The scope of this in-silico study is to phylogenetically analyse 2 individual groups of selected prokaryotes, on the basis of their LuxA and LuxS proteins, separately, so as to determine the interrelationships amongst those diverse groups of bacteria and to provide an insight into their evolution with the help of bioinformatics. Total 17 species of bacteria were chosen for phylogenetic analysis of LuxA protein, that codes for the alpha-subunit of luciferase enzyme responsible for control of bioluminescence in these organisms. Most of these were found to be marine, bioluminescent, Gram-negative bacteria, with a few exceptions ranging from endophytes of sugarcane to noduleforming soil bacteria that differ drastically from the rest in terms of habitat and mode of survival. For the phylogenetic analysis of LuxS protein, 25 species of bacteria were selected, showing highly varied characteristics in terms of habitat, modes of survival etc., most of which are well-known pathogens of humans and animals. The presence of LuxS in these organisms indicates the role of quorum sensing in the development of numerous diseases caused by these pathogens. This insilico study aims firstly at understanding the phylogeny of $\mathrm{NifH}$ protein (Nitrogenase reductase), out of the whole enzyme complex. The basis of work is to focus on the most conserved domain, NifH. Secondly, it emphasizes on understanding the individual contribution of LuxA and LuxS in the evolution of quorum sensing mechanism in the chosen species of bacteria.

While LuxA codes for the alpha subunit of luciferase enzyme of most of the bioluminescent bacteria, its role in non-luminiscent bacteria is yet to be fathomed. S-Ribosylhomocysteinase (LuxS) is an $\mathrm{Fe}(2+)$-dependent metalloenzyme that catalyzes the cleavage of the thioether bond in Sribosylhomocysteine (SRH) to produce homocysteine and DPD, the precursor of Al-2 molecule [23]. Presumably, quorum sensing bestows upon bacteria some of the qualities of higher organisms. The evolution of quorum sensing systems in bacteria could, therefore, have been one of the early steps in the development of multicellularity [26, 27, 29].

\section{METHODS \\ Sequence Retrieval: Protein (nitrogenase reductase, luciferase alpha-subunit, S-} ribosylhomocysteine lyase) sequences (full length) belonging to different genera were retrieved from NCBI and UniProt Protein Databases. Processing of data: Sequences in the GenPept format were converted to the FASTA format and compiled together in a single text file. ClustalW: Used to obtain Multiple Sequence Alignment with the help of default parameters.

Seqboot: Seqboot is a general bootstrapping and data set translation tool of PHYLIP.

Proml: This module of PHYLIP makes use of the Maximum likelihood method for the construction of phylogenetic tree. This module was chosen over the Maximum Parsimony and Distance methods as it is more efficient and reliable, despite taking greater time to process the data. The method uses probability calculations to generate a tree that best accounts for variation in a set of sequences.

Input file: The outfile from seqboot

Parameters given to the module were:

i) Dataset number $=100$

ii) Random seed number $=1$

iii) Jumble number $=1$ (This was done to minimize the processing time.)

Output files: Two files were generated. -- outfile and outtree.

Consense: Consense module of PHYLIP reads a file of computer-readable trees and prints out a consensus tree. The tree printed out has at each fork a number indicating how many times the group which consists of the species to the right of (descended from) the fork occurred. Input file: The outtree from Proml.

Output file: It is the final outtree displaying bootstrap values at every node. TreeView, 
FigTree: To view the final outtree obtained from Consense.

\section{RESULTS AND DISCUSSION Phylogeny of Nitrogen-Fixing Bacteria on the basis of NifH protein}

Nitrogenase reductase is a functionally constant protein catalyzing $\mathrm{N} 2$ reduction, which is found in many phylogenetic lineages of Archaeabacteria, Proteobacteria, Cyanobacteria, Actinobacteria and Diazotrophs. A phylogenetic analysis of nifH genes may provide insights into the evolution of the bacterial genomes. However, due to wobblebase degeneracies, the third base in the codons of a protein-coding gene is of little value in the analysis of distantly related proteins. Translation of DNA into 21 different types of codon (20 amino acids and a terminator) allows the information to sharpen up considerably. Wrong frame information is set aside. As a result of the translation procedure the protein sequences with their 20 amino acids are much easier to align than the corresponding DNA sequences with only 4 nucleotides. The signal to noise ratio is greatly improved when using protein sequences over DNA sequences.

Fig.2 (a) denotes dark and light columns indicating conserved and less conserved regions of the chosen sequences, respectively. This is an output of ClustalW software used for discriminating nitrogenase reductase protein sequences. This forms the baseline data for generation of Phylogenetic trees. Alignment quality may have much impact on phylogenetic reconstruction. Not only the alignment algorithm, but also the method used to deal with the most problematic alignment regions, or gaps, may have a critical effect on the final tree. Although some authors remove such problematic regions, either manually or using automatic methods, in order to improve phylogenetic performance, others prefer to keep such regions to avoid losing any information. [13,14] .The present study adopts the latter strategy.

A figure 3, 4 shows the same Phylogenetic tree in different tree-viewing formats. The numerical value at each node indicates the bootstrap value supporting every split in the lineage.Fig. 3 is an unrooted phylogenetic tree in the Radial format, an output of Proml module of PHYLIP that can be viewed and analyzed in Treeview or FigTree Software. Unrooted trees illustrate the relatedness of the leaf nodes without making assumptions about common ancestry. The coloured clusters indicate the evolutionary links amongst the microorganisms chosen for the present study. Rectangular Cladogram, an output of Proml. This type of tree only represents a branching pattern, i.e., its branch lengths do not represent time.Fig. 4 is a Phylogram of nifH gene, a phylogram is a phylogenetic tree that explicitly represents the rate of evolution of organisms; where the number of character changes in the protein is directly proportional to branch lengths. The resulting Phylogenetic tree indicates that Bradyrhizobium japonicum forms a distinct branch, dividing the other 29 organisms in a separate cluster. This shows that the nitrogenase reductase of Bradyrhizobium japonicum distantly relates to that of the other chosen protein sequences, being the farthest from Desulfovibrio vulgaris and Chlorobium phaeobacteriodes. It also appears to be a closer relative of Azorhizobium spp. than to other Rhizobiaceae group members.

The wet lab studies (unpublished data) conducted on samples of Bradyrhizobium japonicum from soyabean legume nodes from three geographically distinct locations have failed. All the three times, Rhizobium spp. was found to grow on the selective media, instead of Bradyrhizobium spp., considering the ability of the former to show faster growth than the latter. This observation when coupled with the above Phylogenetic tree branching suggests resequencing of the protein. The other probable reason to have obtained this kind of branching could be the low accuracy level of the sequence. The main cluster that encompasses the rest of the prokaryotes divides them further on the basis of their nitrogenase reductase protein sequences. Supported by a $100 \%$ bootstrap value is the monophyletic cluster of Xanthobacter autotrophicus and Azorhizobium caulinodans, both belonging to the Xanthobacteraceae family. The cluster indicates that they have evolved at the same rate; a result also seen during phylogenetic analysis of nifH genes of the two organisms. Both share common properties of being aerobic chemoorganotrophs. Further, Burkholderia xenovorans, a free-living soil microbe, appears to be monophyletic with the common ancestor of Polaromonas naphthalenivorans and Cupriavidus taiwanensis. All three of these organisms are known to possess heavy-metal absorption and pollutant degrading abilities.

Another cluster showing greater evolution on the basis of the change in their nitrogenase reductase sequence comprises of closely related Anabaena spp, Nostoc spp and Cyanothece spp., all of which are photosynthetic cyanobacteria that serve as a link between bacterial and algal life-forms. This group is phylogenetically closest to the actinobacteria (Frankia spp.) and Paenibacillus graminis, both symbiotic heterotrophs. Rhizobium leguminosarum and Sinorhizobium meliloti, both of which are nodule-forming symbionts of leguminous plants, seem to possess a nearly similar nitrogenase reductase enzyme. They are monophyletic with Gluconacetobacter diazotrophicus, an endophyte of sugarcane; and Zymomonas mobilis, a fermentative bacteria 
surviving on sugar-rich plant saps. A bootstrap value of $63 \%$ supports the grouping of Rhodobacter sphaeroides and Rhodospirillum rubrum, two photosynthetic proteobacteria. Thus, the enzyme appears to have undergone minimal changes in both these species. The most highly evolved group of organisms with respect to their nitrogenase reductase protein is that of Desulfovibrio vulgaris and Chlorobium phaeobacteriodes. These two species are the most distantly spaced from the initial node, this indicates that their nitrogenase reductase enzyme sequence has undergone maximum sequence changes. Both the species are strict anaerobes, though the former is a heterotroph, while the latter is a free-living aquatic photoautotroph. Syntrophobacter fumaroxidans, a free-living anaerobic heterotroph seems to have arisen from the same ancestor as that of this cluster. Methanothermobacter thermoautotrophicus and Methanococcus maripaludis together form a cluster of methanogenic archae that closely follows the one above, which indicates that despite being the most primitive forms of organisms, the archae bacteria still may possess nitrogenase reductase protein that is capable of undergoing constant changes during evolution. This could be due to their vast tenacity to sustain extreme environmental pressure, helping them to adapt faster. This group is monophyletic with another cluster formed by Methanosarcina acetivorans and Clostridium kluyveri, both strict anaerobes. The tree shows that the other species of the Clostridium genus i.e., Clostridium pasteurianum is phylogenetically closest to Desulfotomaculum reducens and Acidithiobacillus ferrooxidans.

\section{Phylogeny of Quorum Sensing Bacteria on the basis of Lux proteins}

The evolutionary patterns of quorum sensing bacteria belonging to various genera were obtained in the form of Phylograms, Cladograms and unrooted radial trees. The baseline data for tree construction was obtained through ClustalW software, the output of which is depicted in Fig: 2(b). Multiple Sequence Alignment not just allows the identification of conserved domains in a protein sequence, but also distinguishes amino acid residues at given sequence positions in terms of their physico-chemical properties

Fig 6 shows a phylogram based on LuxS protein, indicating distinct evolutionary links amongst 25 species of bacteria that include marine, luminous bacteria, endophytes, lactic acid bacteria, extremophiles and potential pathogens, on the scale of time, assuming that all sequence changes occurring naturally in a protein are a function of time, owing to individual molecular clocks of every organism. Vibrio cholerae appears to possess the most primitive form of LuxS protein, closest phylogenetically to Vibrio harveyi and Vibrio fischeri. Supported by a bootstrap value of 100 , the lactic acid bacteria stand out as a distinct, advanced cluster including Lactobacillus acidophilus, Leuconostoc mesenteroides, Bifidobacterium longum and Streptococcus thermophilus, all being Gram positive, facultative anaerobes that ferment milk sugars. Streptococcus mutans, a ubiquitous pathogen known to cause dental caries through biofilm formation is closest to the cluster mentioned above. Two of the commensals of the human gut, potent opportunistic pathogens Klebsiella pneumoniae and Escherichia coli also appear to have evolved from a same primitive ancestor that is evolutionally closest to Photorhabdus luminescens, a bioluminescent symbiont of soil nematodes, and Proteus mirabilis, a well-known etiological agent of nosocomial infections. Bacillus thuringiensis and Bacillus subtilis , Gram positive, aerobic, endospore-forming soil bacteria, hold the most highly evolved forms of LuxS protein, forming the rightmost cluster in the phylogram, supported by a bootstrap value- 97. Two extremophilic chemoorganotrophs, Deinococcus radiodurans and Thermus thermophilus have been grouped together in a monophyletic cluster, indicating the existence of a common ancestor. Fig. 5 show another phylogram that appropriately groups 17 chosen species on the basis of their LuxA protein. Helicobacter Canadensis, an emerging human pathogen with diverse animal reservoirs forms an entirely divergent branch, grouping 16 other chosen bacteria with a bootstrap value of 100 , into two separate clusters. One consisting of all the marine, bioluminescent bacteria including those of Photorhabdus spp., Shewanella spp., and Vibrio spp., together in the same monophyletic clade, and the second, showing a possible evolutionary link between obtained LuxA sequences of Gluconacetobacter diazotrophicus , Bradyrhizobium japonicum and Rhizobium spp. The most highly evolved species amongst the chosen bacteria, showing the maximum number of sequence changes in their LuxA protein are Photorhabdus asymbiotica and Photorhabdus luminescens, both bioluminescent Gram negative microbes, the former is a known insect pathogen while the latter is a symbiont of soil nematodes.

\section{CONCLUSION}

Use of bioinformatics as an inter-disciplinary approach to study life-forms is immensely useful with respect to phylogenetic analysis. In the present study, construction of Phylogenetic trees of:

I] 30 nitrogen-fixing prokaryotes based on their Nitrogenase reductase enzyme sequence, II] 17 species of quorum sensing bacteria based on their LuxA (enzyme Luciferase alpha subunit) protein sequence and 
III] 25 species of quorum sensing bacteria based on their LuxS (Enzyme S-ribosyl homocysteine lyase) protein sequences was taken up.

The obtained clusters have shown great accordance with the biochemical characteristics of these microorganisms testified in laboratory. $[5,9]$. Phylogenetic analyses, thus, on the basis of highly conserved protein domains, universal in their existence, can provide a preamble to the actual 16S-rRNA based phylogeny or genomic analyses of phylogeny carried out in the wet lab. Therefore, the use of ClustalW and PHYLIP was satisfactory for the chosen work. More intrusive softwares accommodating more than one protein sequences in the same exercise can revolutionize phylogenetic classification. Work by several laboratories has shown that an additional mode of regulation quorum sensing, intercedes in signal exchange process and perhaps plays major role in preparing and coordinating the N2 fixing rhizobium during the establishment of symbiosis. $R$. leguminosarum carries multitiered quorum sensing system that represents one of the most complex regulatory networks identified for this form of gene regulation [11].

Presumably, quorum sensing bestows upon bacteria some of the qualities of higher organisms. The evolution of quorum sensing systems in bacteria could, therefore, have been one of the early steps in the development of multicellularity [26].

\section{ACKNOWLEDGEMENT}

I wish to put on record, my sincere thanks to all those who have spent their precious time giving valuable inputs for the successful accomplishment of this project. I would personally like to thank all my teachers, for guiding me throughout. I would also like to express my deep sense of gratitude towards Dr. Sushama Chaphalkar (Director, VSBT) for her constant support and encouragement.

\section{References}

[1] Jason Raymond, Janet L. Siefert, Christopher R. Staples and Robert E. Blankenship (2004) Mol. Biol. Evol., 21(3):541-554.

[2] Peters John W., Fisher Karl, Dean Dennis R. (1995) Annual Review of Microbiology, Vol. 49: 335-366.

[3] Quok-Cheong Choo, Mohd-Razip Samian, and Nazalan Najimudin (2003) Appl Environ Microbiol., 69(6): 3658-3662.

[4] Cantera Jose Jason L., Kawasaki Hiroko (2004) Seki Tatsuji Microbiology ISSN 1350-0872.

[5] Hurek T., Egener T., Reinhold - Hurek B. (1997) J. Bacteriol., 179(13):4172-8.

[6] Smith R. L., Van Baalen C. and Tabita F. R. (1987) J. Bacteriol., 169(6): 2537-2542.
[7] Berman-Frank I., Lundgren P. and Falkowski P. (2003) Res. Microbiol. 154:157-164.

[8] Glazer A.N., Kechris K.J. (2009) PLoS ONE, 4(7): e6136.

[9] Young J.P.W. (2005) Springer. pp 221-241.

[10] Henson B.J., Watson L.E., Barnum S.R. (2004) J Mol Evol., 58: 390-399.

[11] Juan E. Gonzalez, Melanie M.Marketon (2003) MMBR, 67:574-592.

[12] Schrock R.R. (2005) Philos Transact A 363: 959-969, Discussion 1035-1040.

[13] Talavera G., Castresana J. (2007) Syst Biol., 56(4):564-77.

[14] Phillips A., Janies D., Wheeler W. (2000) Mol. Phylogenet Evol., 16(3):317-30.

[15] Zehr J.P., Mellon M.T. and Hiorns W.D. (1997) Microbiology 143: 1443-1450.

[16] Arp D.J., Triplett, E.W. (2000) Wymondham,Great Britain: Horizon Scientific Press, pp. 1-14.

[17] Donald H. Burke, John E. Hearst. (1993) Evolution, 90, 7134-7138.

[18] Rivas E., Eddy S.R. (2008) PLoS Comput Biol., 4(9):e1000172.

[19] Garrity George M., Brenner Don J., Krieg Noel R., Staley James R. (2005) Springer - Verlag Bergey's Manual of Systematic Bacteriology, Volume Two: The Proteobacteria, Parts $A-C$.

[20] Camilli A. and Bassler B.L. (2006) Science, 311:1113-1116.

[21] Winzer K., Hardie K. R. and Williams P. (2003) Adv. Appl. Microbiol. 53:291396.

[22] Nealson K.H. and Hastings J.W. (1979) Microbiol. Rev. 43: 496-518.

[23] Bassler B.L. (1999) Curr Opin Microbiol 2: 582-587.

[24] Waters C.M. and Bassler B.L. (2005) Ann. Rev. Cell. Dev. Biol. 21: 319-346.

[25] Reading N.C. and Sperandio V. (2006) FEMS Microbiol. Lett., 254: 1-11.

[26] Dunny G. M. and Winans S. C. (1999) Rev 43: 496-518. 1.

[27] Schauder S., Shokat K., Surette M.G., Bassler B.L. (2001) Mol Microbiol. 41(2):463-76.

[28] Gobbetti M., De Angelis M., Di Cagno R., Minervini F., Limitone A. (2007) Int $J$ Food Microbiol.; 120(1-2):34-45.

[29] Mount W. (2001) Bioinformatics - Sequence and Genome Analysis. Ed (1). 


$$
10 \quad 20 \quad 30
$$

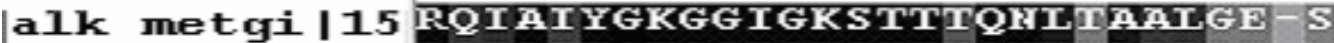

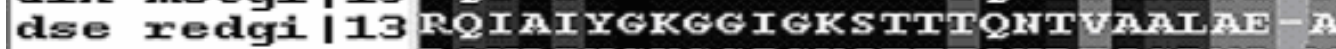
clos pasgi. I RQUAIYGKGGIGKSTIIQRLISGLHA-1

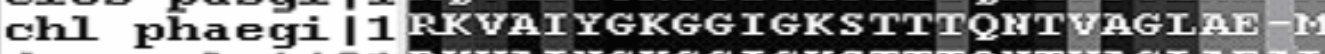

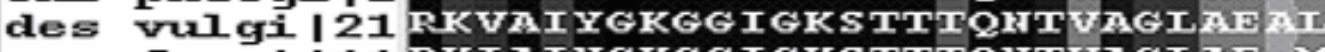
sym fumgi I 11 RKI AIYGKGGIGKSTIIQHT IGI

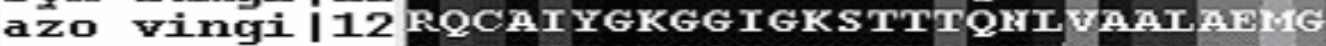

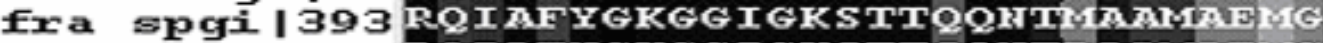
ana spgi I 759 RQI AFYGKGGIGKSTTSQHTI AMHARG

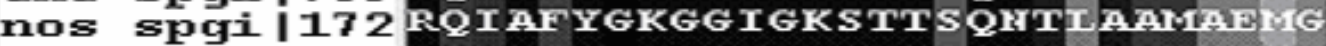

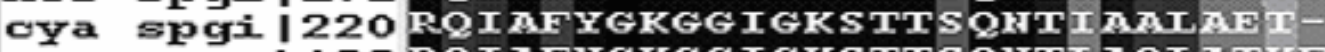
pae gragi I 22 RQIAFYGKGGIGKSTTSQRTIAQLATRE

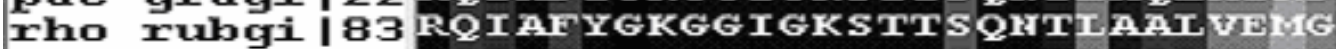

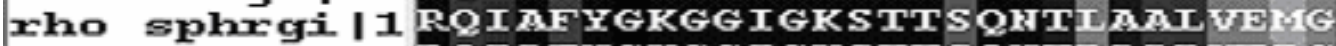
rhiz leggi | 2 RQIAFYGKGGIGKSTTSQHTI AMT ISIG sin mel gí I 16 ReI AFYGKGGIGKSTTSQHTI AMT UDIG glu diagi I 20 RQI AEXGKGGIGKSTTSQRTIRALVISG zym mobgi | 56 RQI AFYGKGGIGKSTTSQHTI AMT USIG azo Caugi I 12 ReI AFYGKGGIGKSTTSQHTIAATAVNG

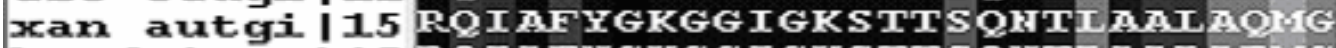
brad japgi I 2 RQIAFYGKGGIGKSTTSQHTI AMT AISG

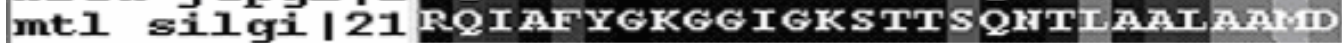

RRIBI

IXIRUT

KIIrTh

लिखण्या

IRxणry

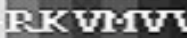

KXYIII

IKIU⿴囗十

ORIII

QRIII

IXRIXI

ORIII

QRIII

QKIIIT

OKIII

QXIIIV

OKILI

OKIII

HRIIIt

HRI工I

QKIII

exIIIT

Fig. 2(a) - Multiple Sequence Alignment of $\mathrm{NifH}$ protein sequences.

$\begin{array}{lll} & & 10\end{array}$

\begin{tabular}{|l|l|l|}
\hline AVFPMILW & RED & Small (small+ hydrophobic (incl.aromatic - Y)) \\
\hline DE & BLUE & Acidic \\
\hline RK & MAGENTA & Basic \\
\hline STYHCNGQ & GREEN & Hydroxyl + Amine + Basic - Q \\
\hline Others & Gray & \\
\hline
\end{tabular}

Fig. 2(b)- Multiple sequence alignment of LuxA protein as obtained from ClustalW. The given colour code group's specific amino acids on the basis of their properties 


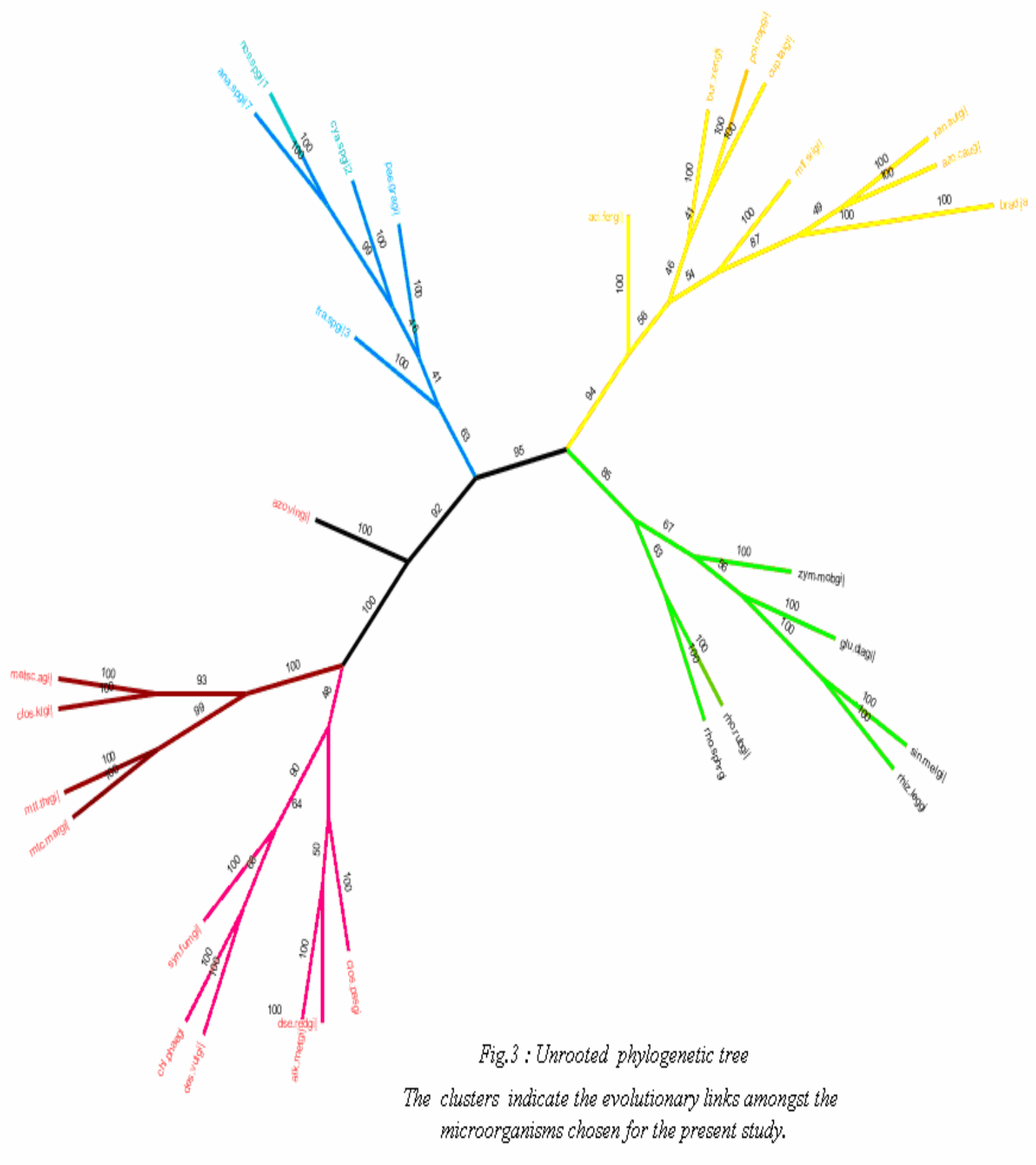

Fig. 3- Unrooted Phylogenetic tree 


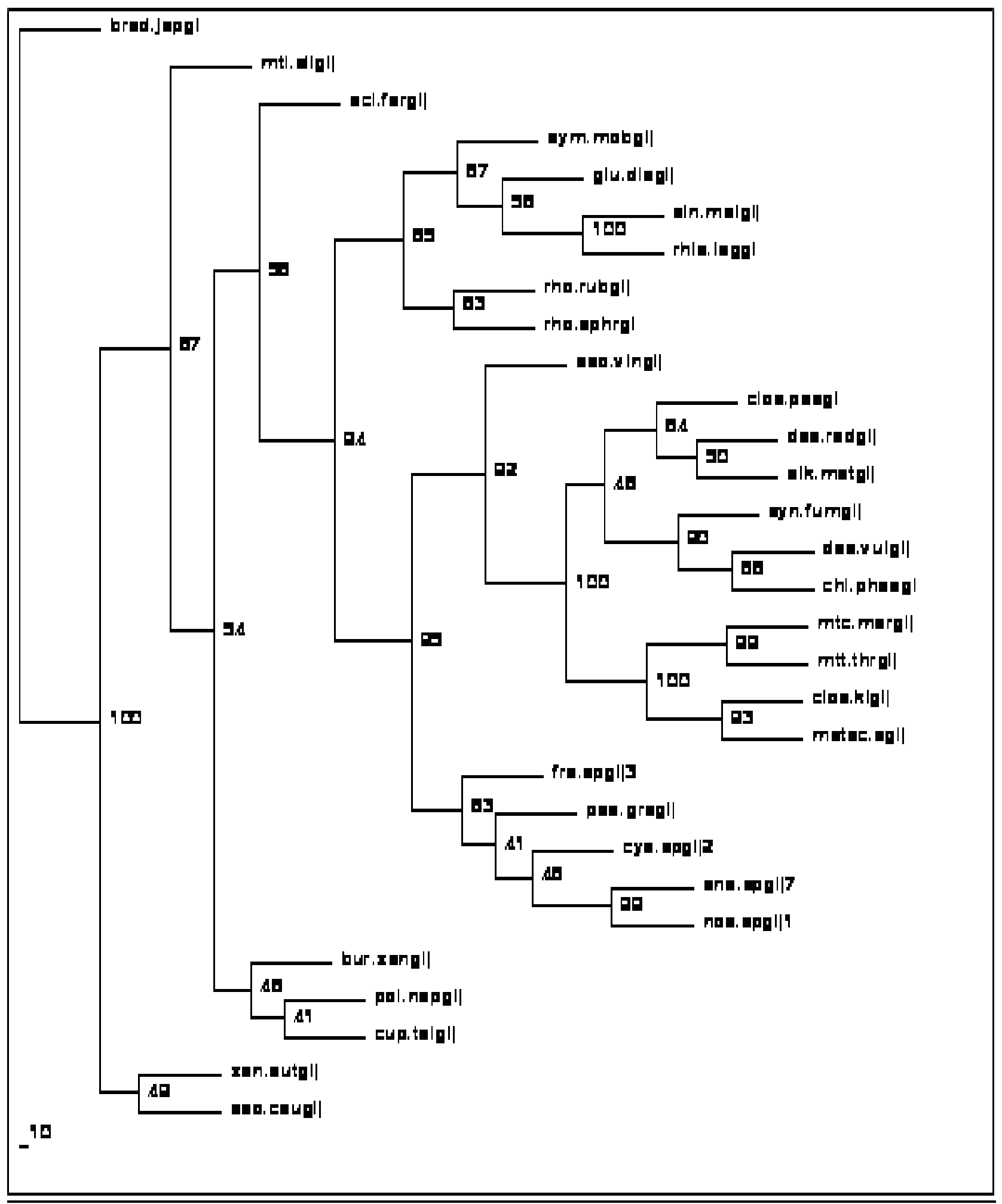

Fig. 4- NifH gene in 30 N2 fixing bacteria showing phylogenetic relationship through phylogram 


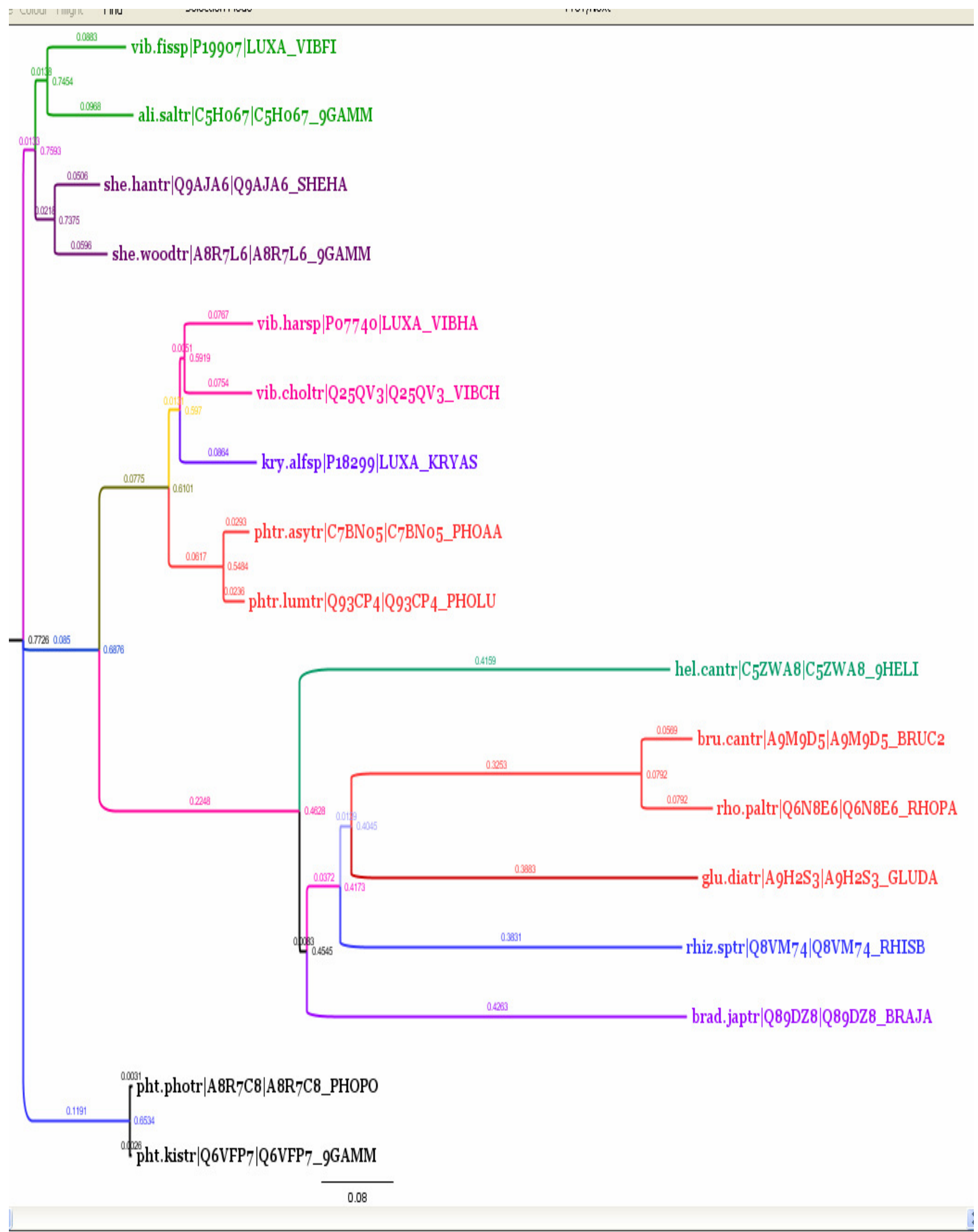

Fig. 5- LuxA Phylogram 17 spp. 


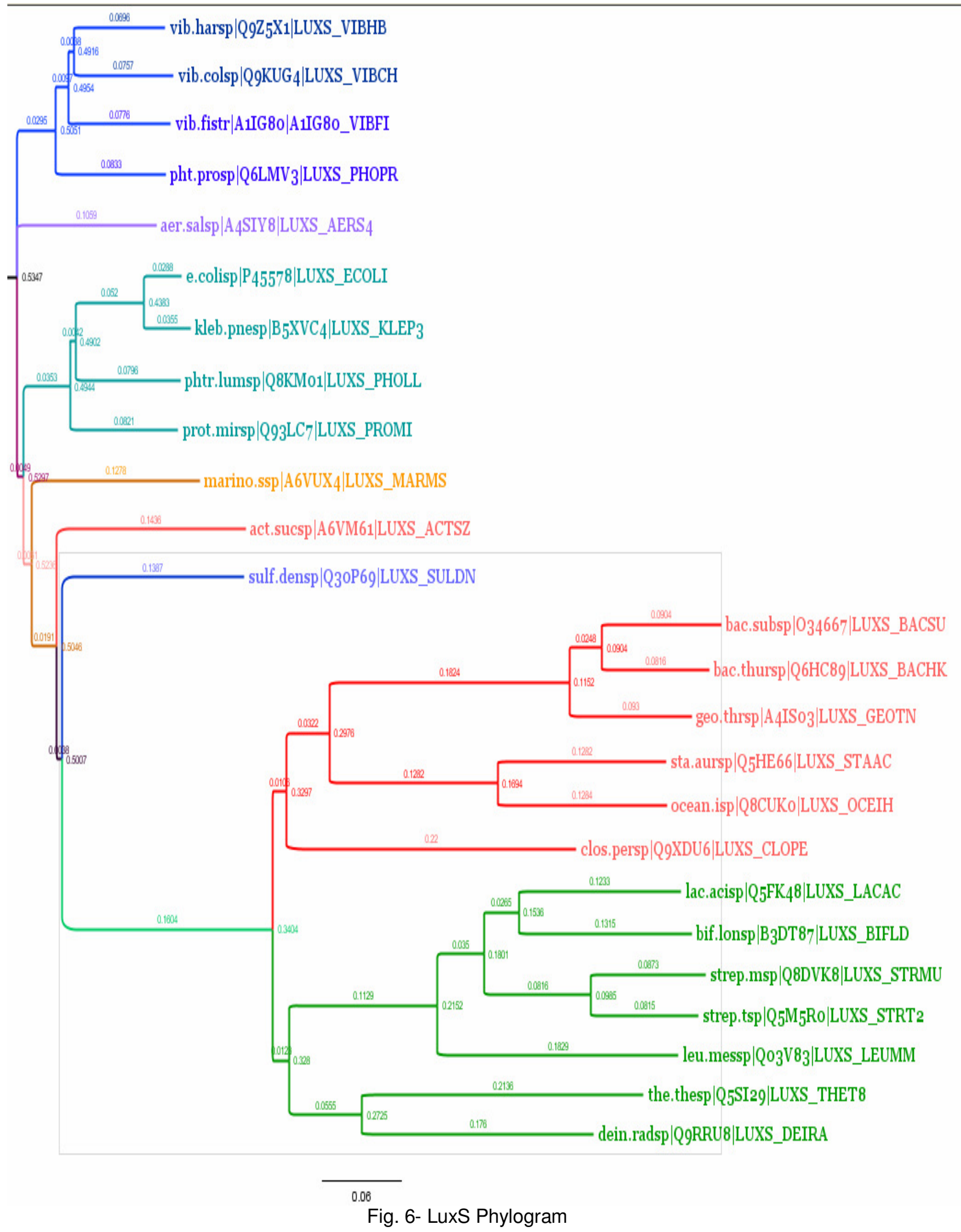


Table 1-A table summarizing general features of the organisms studied under Phylogenetic analysis of nitrogen-fixing bacteria on the basis of NifH protein

\begin{tabular}{|c|c|c|c|c|c|}
\hline $\begin{array}{l}\text { Sr. } \\
\text { No }\end{array}$ & Organism & Abbr. & Gl number & Taxonomy & Special Features \\
\hline 1 & $\begin{array}{l}\text { Azorhizobium } \\
\text { caulinodans }\end{array}$ & azo.cau & gi|128206 & $\begin{array}{l}\text { Bacteria; Proteobacteria; } \\
\text { Alphaproteobacteria; Rhizobiales; } \\
\text { Xanthobacteraceae; Azorhizobium }\end{array}$ & $\begin{array}{l}\text { Nodule forming, } \\
\text { Motile, hydrogen- } \\
\text { oxidizing } \\
\text { bacterium. }\end{array}$ \\
\hline 2 & $\begin{array}{l}\text { Methanococcus } \\
\text { maripaludis }\end{array}$ & mtc.mar & gi|159906184 & $\begin{array}{l}\text { Archaea; Euryarchaeota; Methanococci; } \\
\text { Methanococcales; Methanocaldococcaceae; } \\
\text { Methanococcus; maripaludis. }\end{array}$ & $\begin{array}{l}\text { Methanogenic } \\
\text { nitrogen fixer. } \\
\text { Irregular shaped } \\
\text { cocci. }\end{array}$ \\
\hline 3 & $\begin{array}{l}\text { Rhodospirillum } \\
\text { rubrum }\end{array}$ & rho.rub & gi|83592346 & $\begin{array}{l}\text { Bacteria, Proteobacteria, } \\
\text { Alphaproteobacteria, Rhodospirillales, } \\
\text { Rhodospirillaceae, Rhodospirillum. }\end{array}$ & $\begin{array}{l}\text { Fermentative, } \\
\text { Spiral shaped, } \\
\text { purple bacterium. }\end{array}$ \\
\hline 4 & $\begin{array}{l}\text { Methanothermobacter } \\
\text { thermoautotrophicus }\end{array}$ & mtt.thr & gi|15679556 & $\begin{array}{l}\text { Archaea; Euryarchaeota; Methanobacteria; } \\
\text { MethanobacteriaceaeMethanothermobacter. }\end{array}$ & $\begin{array}{l}\text { Metahnogenic, } \\
\text { non-motile. }\end{array}$ \\
\hline 5 & Methylocella silvestris & mtl.sil & gi|217979732 & $\begin{array}{l}\text { Bacteria; Proteobacteria; } \\
\text { Alphaproteobacteria; Rhizobiales; } \\
\text { Beijerinckiaceae; Methylocella. }\end{array}$ & $\begin{array}{l}\text { Non-pigmented, } \\
\text { non-motile, } \\
\text { facultatively } \\
\text { methane-oxidizing } \\
\text { organism }\end{array}$ \\
\hline 6 & $\begin{array}{l}\text { Alkaliphilus } \\
\text { metalliredigens }\end{array}$ & alk.met & gi|150391261 & $\begin{array}{l}\text { Bacteria, Firmicutes Clostridia, } \\
\text { Clostridiales, Clostridiaceae, Alkaliphilus } \\
\text { metalliredigens. }\end{array}$ & $\begin{array}{l}\text { Metal-reducing } \\
\text { bacterium. }\end{array}$ \\
\hline 7 & $\begin{array}{l}\text { Desulfotomaculum } \\
\text { reducens }\end{array}$ & dse.red & gi|134300654 & $\begin{array}{l}\text { Bacteria; Firmicutes; Clostridia; } \\
\text { Clostridiales; Peptococcaceae; } \\
\text { Desulfotomaculum. }\end{array}$ & $\begin{array}{l}\text { Sulfate reducer, } \\
\text { Metal reducer. }\end{array}$ \\
\hline 8 & Anabaena spp. & ana.sp & gi|75910675 & $\begin{array}{l}\text { Bacteria; Cyanobacteria; Nostocales; } \\
\text { Nostocaceae; Anabaena }\end{array}$ & $\begin{array}{l}\text { Heterocyst forming } \\
\text { nitrogen reducers. }\end{array}$ \\
\hline 9 & $\begin{array}{l}\text { Rhodobacter } \\
\text { sphaeroides }\end{array}$ & rho.sphr & gi|126462953 & $\begin{array}{l}\text { Bacteria; Proteobacteria; } \\
\text { Alphaproteobacteria; Rhodobacterales; } \\
\text { Rhodobacteraceae; Rhodobacter. }\end{array}$ & $\begin{array}{l}\text { Motile, sustains } \\
\text { wide range of } \\
\text { growth conditions. }\end{array}$ \\
\hline 10 & $\begin{array}{l}\text { Azotobacter } \\
\text { vinelandii }\end{array}$ & azo.vin & gi|128203 & $\begin{array}{l}\text { Bacteria; Proteobacteria; } \\
\text { Gammaproteobacteria; Pseudomonadales; } \\
\text { Pseudomonadaceae Azotobacter. }\end{array}$ & $\begin{array}{l}\text { Phytohormones, } \\
\text { vitamin producer. } \\
\text { Xenobiotic } \\
\text { degrader. }\end{array}$ \\
\hline 11 & $\begin{array}{l}\text { Rhizobium } \\
\text { leguminosarum }\end{array}$ & rhiz.leg & gi|209547092 & $\begin{array}{l}\text { Bacteria; Proteobacteria; } \\
\text { Alphaproteobacteria; Rhizobiales; } \\
\text { Rhizobiaceae; Rhizobium. }\end{array}$ & $\begin{array}{l}\text { Nodule- forming } \\
\text { nitrogen fixer. } \\
\text { Motile. }\end{array}$ \\
\hline 12 & Clostridium kluyveri & clos.kl & gi|153954373 & $\begin{array}{l}\text { Bacteria; Firmicutes; Clostridia; } \\
\text { Clostridiales; Clostridiaceae; Clostridium. }\end{array}$ & $\begin{array}{l}\text { Can grow on } \\
\text { ethanol and } \\
\text { acetate media. }\end{array}$ \\
\hline 13 & $\begin{array}{l}\text { Clostridium } \\
\text { pasteurianum }\end{array}$ & clos.pas & gi|128204 & $\begin{array}{l}\text { Bacteria; Firmicutes; Clostridia; } \\
\text { Clostridiales; Clostridiaceae; Clostridium. }\end{array}$ & Fermentative. \\
\hline 14 & Nostoc spp. & nos.sp & gi|17228949 & $\begin{array}{l}\text { Bacteria; Cyanobacteria; Nostocales; } \\
\text { Nostocaceae, Nostoc. }\end{array}$ & $\begin{array}{l}\text { Motile, gelatinous, } \\
\text { sustains extreme } \\
\text { climates. }\end{array}$ \\
\hline 15 & $\begin{array}{l}\text { Bradyrhizobium } \\
\text { japonicum }\end{array}$ & brad.jap & gi|27376880 & $\begin{array}{l}\text { Bacteria; Proteobacteria; } \\
\text { Alphaproteobacteria; } \\
\text { Bradyrhizobiaceae;Bradyrhizobium }\end{array}$ & $\begin{array}{l}\text { Nodule- forming } \\
\text { nitrogen fixer. }\end{array}$ \\
\hline $\begin{array}{l}\text { Sr. } \\
\text { No }\end{array}$ & Organism & Abbr. & GI number & Taxonomy & Special Features \\
\hline 16 & Cyanothece spp. & cya.sp & gi|2209097 & $\begin{array}{l}\text { Bacteria; Cyanobacteria; Chroococcales; } \\
\text { Cyanothece. }\end{array}$ & Unicellular. \\
\hline 17 & $\begin{array}{l}\text { Syntrophobacter } \\
\text { fumaroxidans }\end{array}$ & syn.fum & gi|116748461 & $\begin{array}{l}\text { Bacteria; Proteobacteria; } \\
\text { DeltaproteobacteriaSyntrophobacterales; } \\
\text { Syntrophobacteraceae; Syntrophobacter }\end{array}$ & $\begin{array}{l}\text { Syntrophic, } \\
\text { propionate- } \\
\text { oxidizing. Non- } \\
\text { motile bacterium. }\end{array}$ \\
\hline 18 & Chlorobium & chl.phae & gi|119356577 & Bacteria; Chlorobi group;Chlorobia; & Green-sulphur \\
\hline
\end{tabular}




\begin{tabular}{|c|c|c|c|c|c|}
\hline & phaeobacteriodes & & & Chlorobiales; Chlorobiaceae; Chlorobium. & $\begin{array}{l}\text { bacterium. Non- } \\
\text { motile. }\end{array}$ \\
\hline 19 & $\begin{array}{l}\text { Cupriavidus } \\
\text { taiwanensis }\end{array}$ & cup.tai & gi|188591635 & $\begin{array}{l}\text { Bacteria; Proteobacteria; } \\
\text { Betaproteobacteria; Burkholderiales; } \\
\text { Burkholderiaceae; Cupriavidus. }\end{array}$ & $\begin{array}{l}\text { Motile, helps host } \\
\text { plant in the } \\
\text { absorption of } \\
\text { heavy metals. }\end{array}$ \\
\hline 20 & $\begin{array}{l}\text { Acidithiobacillus } \\
\text { ferrooxidans }\end{array}$ & aci.fer & gi|198283364 & $\begin{array}{l}\text { Bacteria; Proteobacteria; } \\
\text { Gammaproteobacteria; Acidithiobacillales; } \\
\text { Acidithiobacillaceae; Acidithiobacillus }\end{array}$ & $\begin{array}{l}\text { Metabolizes iron } \\
\text { and sulfur. Fixes } \\
\mathrm{CO} 2 \text { and N2. }\end{array}$ \\
\hline 21 & Desulfovibrio vulgaris & des.vul & gi|218887699 & $\begin{array}{l}\text { Bacteria; Proteobacteria; } \\
\text { Deltaproteobacteria Desulfovibrionales; } \\
\text { Desulfovibrionaceae; Desulfovibrio. }\end{array}$ & $\begin{array}{l}\text { Corrodes metals. } \\
\text { Degrades } \\
\text { radioactive waste. }\end{array}$ \\
\hline 22 & $\begin{array}{l}\text { Gluconacetobacter } \\
\text { diazotrophicus }\end{array}$ & glu.dia & gi|209543735 & $\begin{array}{l}\text { Bacteria; Proteobacteria; } \\
\text { Alphaproteobacteria; Rhodospirillales; } \\
\text { Acetobacteraceae; Gluconacetobacter. }\end{array}$ & $\begin{array}{l}\text { Utilizes sucrose } \\
\text { only, diazotrophic. }\end{array}$ \\
\hline 23 & $\begin{array}{l}\text { Xanthobacter } \\
\text { autotrophicus }\end{array}$ & xan.aut & gi|154244101 & $\begin{array}{l}\text { Bacteria; Proteobacteria; } \\
\text { Alphaproteobacteria; Rhizobiales; } \\
\text { Xanthobacteraceae; Xanthobacter }\end{array}$ & $\begin{array}{l}\text { Degrades } \\
\text { halogenated } \\
\text { hydrocarbons. } \\
\text { Biofilm former. }\end{array}$ \\
\hline 24 & Sinorhizobium meliloti & sin.mel & gi|16262902 & $\begin{array}{l}\text { Bacteria; Proteobacteria; } \\
\text { Alphaproteobacteria; Rhizobiales; } \\
\text { Rhizobiaceae; Sinorhizobium }\end{array}$ & Nodule- former. \\
\hline 25 & $\begin{array}{l}\text { Burkholderia } \\
\text { xenovorans }\end{array}$ & bur.xen & gi|91778641 & $\begin{array}{l}\text { Bacteria; Proteobacteria; } \\
\text { Betaproteobacteria; Burkholderiales; } \\
\text { Burkholderiaceae; Burkholderia }\end{array}$ & $\begin{array}{l}\text { Pollutatnt } \\
\text { degrader. Large } \\
\text { genome. }\end{array}$ \\
\hline 26 & Frankia spp. & fra.sp & gi|393471 & $\begin{array}{l}\text { Bacteria; Actinobacteria; Actinobacteria; } \\
\text { Actinobacteridae Actinomycetales; } \\
\text { Frankineae; Frankiaceae; Frankia. }\end{array}$ & Nodule-former. \\
\hline 27 & Zymomonas mobilis & zym.mob & gi|56552719 & $\begin{array}{l}\text { Bacteria; Proteobacteria; Alpha } \\
\text { Proteobacteria; Sphingomonadales; } \\
\text { Sphingomonadaceae; Zymomonas. }\end{array}$ & $\begin{array}{l}\text { Bioethanol } \\
\text { producer. } \\
\text { Hopanoids in } \\
\text { membrane tolerate } \\
\text { alcohol. }\end{array}$ \\
\hline 28 & $\begin{array}{l}\text { Methanosarcina } \\
\text { acetivorans }\end{array}$ & metsc.a & gi|20090077 & $\begin{array}{l}\text { Archaea; Euryarchaeota; Methanomicrobia; } \\
\text { Methanosarcinales; Methanosarcinaceae; } \\
\text { Methanosarcina. }\end{array}$ & $\begin{array}{l}\text { Methanogenic, } \\
\text { Large } \\
\text { genome.Motile. }\end{array}$ \\
\hline 29 & $\begin{array}{l}\text { Paenibacillus } \\
\text { graminis }\end{array}$ & pae.gra & gi|223972582 & $\begin{array}{l}\text { Bacteria; Firmicutes; Bacilli; Bacillales; } \\
\text { Paenibacillaceae; Paenibacillus. }\end{array}$ & $\begin{array}{l}\text { Endospore former. } \\
\text { Motile. }\end{array}$ \\
\hline 30 & $\begin{array}{l}\text { Polaromonas } \\
\text { naphthalenivorans }\end{array}$ & pol.nap & gi|121605244 & $\begin{array}{l}\text { Bacteria; Proteobacteria; Beta } \\
\text { proteobacteria;Comamonadaceae }\end{array}$ & $\begin{array}{l}\text { Naphthalene } \\
\text { degrader. }\end{array}$ \\
\hline
\end{tabular}


Table 2- A table summarizing the characteristics of microorganisms studied under Phylogenetic analysis of quorum sensing bacteria on the basis of their LuxA protein

\begin{tabular}{|c|c|c|c|c|}
\hline $\begin{array}{l}\text { Sr. } \\
\text { No }\end{array}$ & Bacterium & Taxonomy & Abbreviation & Characteristics \\
\hline 1 & Vibrio fischeri & $\begin{array}{l}\text { Bacteria } \quad \text { Proteobacteria } \\
\text { Gammaproteobacteria } \\
\text { Vibrionales } \\
\text { Aliivibrio }\end{array}$ & Vib.fis & $\begin{array}{l}\text { Gram negative, bioluminescent, } \\
\text { motile, saprotrophic, marine } \\
\text { bacterium. Normal flora of marine } \\
\text { species. }\end{array}$ \\
\hline 2 & Vibrio harveyi & $\begin{array}{l}\text { Bacteria } \quad \text { Proteobacteria } \\
\text { Gammaproteobacteria } \\
\text { Vibrionales Vibrionaceae Vibrio }\end{array}$ & Vib.har & $\begin{array}{l}\text { Facultative anaerobe, Gram negative, } \\
\text { non-motile, bioluminescent, } \\
\text { halophilic, marine bacterium. } \\
\text { Opportunistic pathogen of marine } \\
\text { animals. }\end{array}$ \\
\hline 3 & $\begin{array}{l}\text { Photobacterium } \\
\text { phosphoreum }\end{array}$ & $\begin{array}{lc}\text { Bacteria } & \text { Proteobacteria } \\
\text { Gammaproteobacteria } \\
\text { Vibrionales } & \text { Vibrionaceae } \\
\text { Photobacterium } & \\
\end{array}$ & Pht.pho & $\begin{array}{l}\text { Facultative anaerobe, Gram negative, } \\
\text { bioluminescent, chemoorganotrophic } \\
\text { marine bacterium. Lives in symbiosis } \\
\text { with marine animals. }\end{array}$ \\
\hline 4 & Shewanella hanedai & $\begin{array}{l}\text { Bacteria Proteobacteria } \\
\text { Gammaproteobacteria } \\
\text { Alteromonadales } \\
\text { Shewanellaceae Shewanella }\end{array}$ & She.han & $\begin{array}{l}\text { Gram negative, bioluminescent, } \\
\text { marine bacterium. }\end{array}$ \\
\hline 5 & $\begin{array}{l}\text { Photorhabdus } \\
\text { asymbiotica }\end{array}$ & $\begin{array}{l}\text { Bacteria Proteobacteria } \\
\text { Gammaproteobacteria } \\
\text { Enterobacteriales } \\
\text { Enterobacteriaceae } \\
\text { Photorhabdus }\end{array}$ & Phtr.asy & $\begin{array}{l}\text { Gram negative, insect pathogen. } \\
\text { Opportunistic pathogen in humans. }\end{array}$ \\
\hline 6 & Aliivibrio salmonicida & $\begin{array}{l}\text { Bacteria } \quad \begin{array}{r}\text { Proteobacteria } \\
\text { Gammaproteobacteria }\end{array} \\
\text { Vibrionales } \\
\begin{array}{l}\text { Alivibrio } \\
\text { Vibrionaceae }\end{array}\end{array}$ & Ali.sal & $\begin{array}{l}\text { Gram negative, marine bacterium. } \\
\text { Major fish pathogen. }\end{array}$ \\
\hline 7 & $\begin{array}{l}\text { Helicobacter } \\
\text { canadensis MIT 98- } \\
5491\end{array}$ & $\begin{array}{l}\text { Bacteria Proteobacteria } \\
\text { Epsilonproteobacteria } \\
\text { Campylobacterales } \\
\text { Helicobacteraceae Helicobacter }\end{array}$ & Hel.can & $\begin{array}{l}\text { Microaerophilic, Gram negative, } \\
\text { motile bacterium. Emerging human } \\
\text { pathogen with diverse animal } \\
\text { reservoirs. Causes gastrointestinal } \\
\text { diseases. }\end{array}$ \\
\hline 8 & Brucella canis & $\begin{array}{l}\text { Bacteria Proteobacteria } \\
\text { Alphaproteobacteria Rhizobiales } \\
\text { Brucellaceae Brucella }\end{array}$ & Bru.can & $\begin{array}{l}\text { Gram negative bacterium. Infects } \\
\text { dogs and other canids. }\end{array}$ \\
\hline 9 & $\begin{array}{l}\text { Gluconacetobacter } \\
\text { diazotrophicus }\end{array}$ & $\begin{array}{l}\text { Bacteria Proteobacteria } \\
\text { Alphaproteobacteria } \\
\text { Acetobacteraceae } \\
\text { Gluconacetobacter }\end{array}$ & Glu.dia & $\begin{array}{l}\text { Gram negative, Nitrogen fixing } \\
\text { endophyte of sugarcane. }\end{array}$ \\
\hline 10 & Shewanella woodyi & $\begin{array}{l}\text { Bacteria Proteobacteria } \\
\text { Gammaproteobacteria } \\
\text { Alteromonadales } \\
\text { Shewanellaceae Shewanella }\end{array}$ & She.wood & $\begin{array}{l}\text { Gram negative, bioluminescent, } \\
\text { chemoorganotrophic , marine } \\
\text { bacterium. Degrades pollutants in } \\
\text { water. }\end{array}$ \\
\hline 11 & $\begin{array}{l}\text { Photobacterium } \\
\text { kishitanii }\end{array}$ & 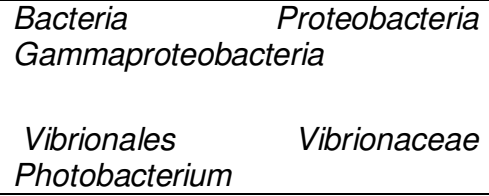 & Pht.kis & $\begin{array}{l}\text { Gram negative, motile, } \\
\text { bioluminescent, marine bacterium. } \\
\text { Symbiotic with marine fishes. }\end{array}$ \\
\hline 12 & $\begin{array}{l}\text { Photorhabdus } \\
\text { luminescens }\end{array}$ & $\begin{array}{l}\text { Bacteria Proteobacteria } \\
\text { Gammaproteobacteria } \\
\text { Enterobacteriales }\end{array}$ & Phtr.lum & $\begin{array}{l}\text { Gram negative, bioluminescent } \\
\text { bacterium. Symbiotic with soil } \\
\text { nematodes. }\end{array}$ \\
\hline
\end{tabular}




\begin{tabular}{|c|c|c|c|c|}
\hline & & $\begin{array}{l}\text { Enterobacteriaceae } \\
\text { Photorhabdus }\end{array}$ & & \\
\hline 13 & $\begin{array}{l}\text { Kryptophanaron alfredi } \\
\text { symbiont }\end{array}$ & $\begin{array}{l}\text { Bacteria Proteobacteria } \\
\text { Gammaproteobacteria } \\
\text { Vibrionales Vibrionaceae }\end{array}$ & Kry.alf & $\begin{array}{l}\text { Bioluminescent, marine bacterium. } \\
\text { Symbiotic with flashlight fishes. }\end{array}$ \\
\hline 14 & Vibrio cholerae & $\begin{array}{l}\text { Bacteria Proteobacteria } \\
\text { Gammaproteobacteria } \\
\text { Vibrionales Vibrionaceae Vibrio }\end{array}$ & Vib.chol & $\begin{array}{l}\text { Aerobic, Gram negative, aquatic, } \\
\text { motile bacterium. Causes Cholera. }\end{array}$ \\
\hline 15 & $\begin{array}{l}\text { Bradyrhizobium } \\
\text { japonicum }\end{array}$ & $\begin{array}{l}\text { Bacteria Proteobacteria } \\
\text { Alphaproteobacteria } \\
\text { Rhizobiales Bradyrhizobiaceae } \\
\text { Bradyrhizobium }\end{array}$ & Brad.jap & $\begin{array}{l}\text { Slow growing, nitrogen fixing, soil } \\
\text { bacterium. Forms nodules in } \\
\text { soyabean roots. }\end{array}$ \\
\hline 16 & $\begin{array}{l}\text { Rhodopseudomonas } \\
\text { palustris }\end{array}$ & $\begin{array}{l}\text { Bacteria Proteobacteria } \\
\text { Alphaproteobacteria } \\
\text { Rhizobiales Bradyrhizobiaceae } \\
\text { Rhodopseudomonas }\end{array}$ & Rho.pal & $\begin{array}{l}\text { Purple, non-sulphur bacterium. } \\
\text { Phototrophic, degrades aromatic } \\
\text { compounds in soil and water. }\end{array}$ \\
\hline 17 & $\begin{array}{l}\text { Rhizobium sp. } \\
\text { BR816) }\end{array}$ & $\begin{array}{l}\text { Bacteria } \\
\text { Alphaproteobacteria } \\
\\
\text { Rhizobiales } \\
\text { Rhizobium }\end{array}$ & Rhiz.sp & $\begin{array}{l}\text { Nitrogen fixing, nodule forming, soil } \\
\text { bacterium symbiotic with roots of } \\
\text { leguminous plants. }\end{array}$ \\
\hline
\end{tabular}


Table 3- A table summarizing the characteristics of microorganisms studied under Phylogenetic analysis of quorum sensing bacteria on the basis of their LuxS protein.

\begin{tabular}{|c|c|c|c|c|}
\hline & & & & \\
\hline Sr.No & Bacterium & Taxonomy & Abbr. & Characteristics \\
\hline 1. & Bacillus subtilis & $\begin{array}{l}\text { Bacteria } \\
\text { Firmicutes } \\
\text { Bacillales } \\
\text { Bacillaceae } \\
\text { Bacillus }\end{array}$ & Bac.sub & $\begin{array}{l}\text { Aerobic, Gram positive, endospore } \\
\text { forming soil bacterium. Causes food } \\
\text { poisoning. }\end{array}$ \\
\hline 2. & Escherichia coli (strain K12) & $\begin{array}{l}\text { Bacteria Proteobacteria } \\
\text { Gammaproteobacteria } \\
\text { Enterobacteriaceae } \\
\text { Escherichia }\end{array}$ & E.coli & $\begin{array}{l}\text { Facultative anaerobe, Gram negative, } \\
\text { normal gut flora, opportunistic } \\
\text { pathogen. }\end{array}$ \\
\hline 3. & Clostridium perfringens & $\begin{array}{l}\text { Bacteria } \\
\text { Firmicutes } \\
\text { Clostridia } \\
\text { Clostridiales Clostridiaceae } \\
\text { Clostridium }\end{array}$ & Clos.per & $\begin{array}{l}\text { Anaerobe, Gram positive, endospore } \\
\text { forming soil bacterium. Causes food } \\
\text { poisoning. }\end{array}$ \\
\hline 4. & $\begin{array}{l}\text { Photorhabdus luminescens } \\
\text { subsp. laumondii }\end{array}$ & $\begin{array}{l}\text { Bacteria Proteobacteria } \\
\text { Gammaproteobacteria } \\
\text { Enterobacteriaceae } \\
\text { Photorhabdus }\end{array}$ & Phtr.lum & $\begin{array}{l}\text { Gram negative, bioluminescent } \\
\text { bacterium. Symbiotic with soil } \\
\text { nematodes. }\end{array}$ \\
\hline 5. & $\begin{array}{l}\text { Geobacillus } \\
\text { thermodenitrificans } \quad \text { (strain } \\
\text { NG80-2) }\end{array}$ & $\begin{array}{l}\text { Bacteria } \\
\text { Firmicutes } \\
\text { Bacillales } \quad \text { Bacillaceae } \\
\text { Geobacillus }\end{array}$ & Geo.thr & $\begin{array}{l}\text { Gram positive, thermophilic, alkane- } \\
\text { degrading, soil bacterium. Isolated from } \\
\text { oil fields. }\end{array}$ \\
\hline 6. & $\begin{array}{l}\text { Klebsiella pneumoniae (strain } \\
\text { 342) }\end{array}$ & $\begin{array}{l}\text { Bacteria Proteobacteria } \\
\text { Gammaproteobacteria } \\
\text { Enterobacteriales } \\
\text { Enterobacteriaceae } \\
\text { Klebsiella } \\
\end{array}$ & Kleb.pne & $\begin{array}{l}\text { Facultative anaerobe, Gram negative, } \\
\text { non-motile, normal gut flora, } \\
\text { opportunistic pathogen. }\end{array}$ \\
\hline 7. & Lactobacillus acidophilus & $\begin{array}{l}\text { Bacteria } \\
\text { Firmicutes Lactobacillales } \\
\text { Lactobacillaceae } \\
\text { Lactobacillus } \\
\end{array}$ & Lac.aci & $\begin{array}{l}\text { Homofermentative, Gram positive, } \\
\text { Acidophilic, milk bacterium. Normal } \\
\text { flora of the body. Probiotic. }\end{array}$ \\
\hline 8. & Leuconostoc mesenteroides & $\begin{array}{l}\text { Bacteria } \\
\text { Firmicutes Lactobacillales } \\
\text { Leuconostoc }\end{array}$ & Leu.mes & $\begin{array}{l}\text { Facultative anaerobe, Gram positive, } \\
\text { ferments milk and vegetables. }\end{array}$ \\
\hline 9. & $\begin{array}{l}\text { Staphylococcus } \\
\text { (strain COL) }\end{array}$ & $\begin{array}{l}\text { Bacteria } \\
\text { Firmicutes } \\
\text { Bacillales Staphylococcus }\end{array}$ & Sta.aur & $\begin{array}{l}\text { Facultative anaerobe, Gram positive } \\
\text { bacterium. Causes wide range of } \\
\text { diseases and nosocomial infections. }\end{array}$ \\
\hline 10. & Streptococcus mutans & $\begin{array}{l}\text { Bacteria } \\
\text { Firmicutes Lactobacillales } \\
\text { Streptococcaceae } \\
\text { Streptococcus }\end{array}$ & Strep.m & $\begin{array}{l}\text { Facultative anaerobe, Gram positive, } \\
\text { biofilm forming bacterium. Causes } \\
\text { dental cavities. }\end{array}$ \\
\hline 11. & Streptococcus thermophilus & $\begin{array}{l}\text { Bacteria } \\
\text { Firmicutes Lactobacillales } \\
\text { Streptococcaceae } \\
\text { Streptococcus }\end{array}$ & Strep.t & $\begin{array}{l}\text { Facultative anaerobe, Gram positive, } \\
\text { thermophilic, homo-fermentative milk } \\
\text { bacterium. }\end{array}$ \\
\hline 12. & Vibrio harveyi & $\begin{array}{l}\text { Bacteria Proteobacteria } \\
\text { Gammaproteobacteria } \\
\text { Vibrionales Vibrionaceae } \\
\text { Vibrio }\end{array}$ & Vib.har & $\begin{array}{l}\text { Facultative anaerobe, Gram negative, } \\
\text { non-motile, bioluminescent, halophilic, } \\
\text { marine bacterium. Opportunistic } \\
\text { pathogen of marine animals. }\end{array}$ \\
\hline 13. & Vibrio cholerae & $\begin{array}{l}\text { Bacteria Proteobacteria } \\
\text { Gammaproteobacteria } \\
\text { Vibrionales Vibrionaceae } \\
\text { Vibrio }\end{array}$ & Vib.chol & $\begin{array}{l}\text { Aerobic, Gram negative, aquatic, motile } \\
\text { bacterium. Causes Cholera. }\end{array}$ \\
\hline 14. & Bacillus thuringiensis & $\begin{array}{l}\text { Bacteria } \\
\text { Firmicutes } \\
\text { Bacillales Bacillaceae }\end{array}$ & Bac.thur & $\begin{array}{l}\text { Aerobic, Gram positive, endospore- } \\
\text { forming, soil bacterium. Biopesticide. }\end{array}$ \\
\hline
\end{tabular}




\begin{tabular}{|c|c|c|c|c|}
\hline & & Bacillus & & \\
\hline 15. & Photobacterium profundum & $\begin{array}{l}\text { Bacteria Proteobacteria } \\
\text { Gammaproteobacteria } \\
\text { Vibrionales Vibrionaceae } \\
\text { Photobacterium } \\
\end{array}$ & Pht.pro & $\begin{array}{l}\text { Aerobic, Gram negative, psychrophiic, } \\
\text { biofilm- forming, bioluminiscent, } \\
\text { halophilic, deep marine bacterium. }\end{array}$ \\
\hline 16. & Oceanobacillus iheyensis & $\begin{array}{l}\text { Bacteria } \\
\text { Firmicutes } \\
\text { Bacillales } \\
\text { Bacillaceae } \\
\text { Oceanobacillus }\end{array}$ & Ocean.i & $\begin{array}{l}\text { Aerobic, Gram positive, extremely } \\
\text { halophilic, alkaliphilic, endospore- } \\
\text { forming, deep marine bacterium. }\end{array}$ \\
\hline 17. & Proteus mirabilis & $\begin{array}{l}\text { Bacteria Proteobacteria } \\
\text { Gammaproteobacteria } \\
\text { Enterobacteriales } \\
\text { Enterobacteriaceae } \\
\text { Proteus }\end{array}$ & Prot.mir & $\begin{array}{l}\text { Facultative anaerobe, Gram negative, } \\
\text { motile bacterium with urease activity. } \\
\text { Causes nosocomial infections. }\end{array}$ \\
\hline 18. & Aeromonas salmonicida & $\begin{array}{l}\text { Bacteria Proteobacteria } \\
\text { Gammaproteobacteria } \\
\text { Aeromonadaceae } \\
\text { Aeromonas }\end{array}$ & Aer.sal & $\begin{array}{l}\text { Facultative anaerobe, Gram negative, } \\
\text { non-motile, marine bacterium. Infects } \\
\text { marine fishes. }\end{array}$ \\
\hline Sr.No & Bacterium & Taxonomy & Abbr. & Characteristics \\
\hline 19. & Marinomonas sp. & $\begin{array}{l}\text { Bacteria Proteobacteria } \\
\text { Gammaproteobacteria } \\
\text { Oceanospirillales } \\
\text { Marinomonas }\end{array}$ & Marino.s & $\begin{array}{l}\text { Aerobe, Gram negative, motile marine } \\
\text { bacterium. Isolated from sea grass. }\end{array}$ \\
\hline 20. & Thermus thermophilus & $\begin{array}{l}\text { Bacteria Deinococcus- } \\
\text { Thermus } \\
\text { Deinococci Thermales } \\
\text { Thermaceae Thermus }\end{array}$ & The.the & $\begin{array}{llr}\text { Aerobe, Gram negative, } & \text { highly } \\
\text { thermophilic, } & \text { chemoorganotrophic } \\
\text { bacterium. Isolated from hot springs. }\end{array}$ \\
\hline 21. & Vibrio fischeri & $\begin{array}{lc}\text { Bacteria } & \text { Proteobacteria } \\
\text { Gammaproteobacteria } \\
\text { Vibrionales } & \text { Vibrionaceae } \\
\text { Aliivibrio } & \\
\text { Alion }\end{array}$ & Vib.fis & $\begin{array}{l}\text { Gram negative, bioluminescent, motile, } \\
\text { saprotrophic, marine bacterium. } \\
\text { Normal flora of marine species. }\end{array}$ \\
\hline 22. & Actinobacillus succinogenes & $\begin{array}{l}\text { Bacteria Proteobacteria } \\
\text { Gammaproteobacteria } \\
\text { Pasteurellales } \\
\text { Pasteurellaceae } \\
\text { Actinobacillus }\end{array}$ & Act.suc & $\begin{array}{l}\text { Facultative anaerobe, Gram negative, } \\
\text { fermentative, pleiomorphic bacterium. } \\
\text { Normal flora of rumen of cattle. }\end{array}$ \\
\hline 23. & Deinococcus radiodurans & $\begin{array}{l}\text { Bacteria Deinococcus- } \\
\text { Thermus } \\
\text { Deinococci Deinococcales } \\
\text { Deinococcaceae } \\
\text { Deinococcus }\end{array}$ & Dein.rad & $\begin{array}{l}\text { Gram positive, Highly resistant, } \\
\text { polyextremophilic, chemoorganotrophic } \\
\text { bacterium. Isolated from organic } \\
\text { material. }\end{array}$ \\
\hline 24. & Bifidobacterium longum & $\begin{array}{l}\text { Bacteria Actinobacteria } \\
\text { Actinobacteridae } \\
\text { Bifidobacteriales } \\
\text { Bifidobacteriaceae } \\
\text { Bifidobacterium }\end{array}$ & Bif.Ion & $\begin{array}{l}\text { Anaerobe, Gram positive, fermentative } \\
\text { bacterium. Normal intestinal flora of } \\
\text { infants. Probiotic. }\end{array}$ \\
\hline 25. & Sulfurimonas denitrificans & $\begin{array}{l}\text { Bacteria Proteobacteria } \\
\text { Epsilonproteobacteria } \\
\text { Campylobacterales } \\
\text { Helicobacteraceae } \\
\text { Sulfurimonas } \\
\end{array}$ & Sulf.den & $\begin{array}{l}\text { Oxidises sulphate, reduces nitrate, } \\
\text { biofilm-forming, chemolithotrophic, } \\
\text { marine bacterium. Isolated from } \\
\text { hydrothermal vents. }\end{array}$ \\
\hline
\end{tabular}

